University of Chicago Law School

Chicago Unbound

Journal Articles

Faculty Scholarship

1982

\title{
Economics, Politics, and the Reading of Statutes and the Constitution
}

Richard A. Posner

Follow this and additional works at: https://chicagounbound.uchicago.edu/journal_articles

Part of the Law Commons

\section{Recommended Citation}

Richard A. Posner, "Economics, Politics, and the Reading of Statutes and the Constitution," 49 University of Chicago Law Review 263 (1982).

This Article is brought to you for free and open access by the Faculty Scholarship at Chicago Unbound. It has been accepted for inclusion in Journal Articles by an authorized administrator of Chicago Unbound. For more information, please contact unbound@law.uchicago.edu. 


\title{
Economics, Politics, and the Reading of Statutes and the Constitution
}

\author{
Richard A. Posner $\dagger$
}

Economists have in recent years begun to study the causes and effects of legislation, and the elements of a positive economic theory of legislation are now in place. ${ }^{1}$ Such a theory would appear to have implications for how judges do, and perhaps for how they should, interpret legislative provisions, both statutory and constitutional. But to date these implications have not been explored

$\dagger$ Judge, United States Court of Appeals for the Seventh Circuit; Senior Lecturer, University of Chicago Law School. The research assistance of Edward Wahl is gratefully acknowledged, as are the helpful comments of David Currie, Frank Easterbrook, Gerald Gunther, Frank Michelman, George Stigler, and Cass Sunstein on a previous draft. This article was conceived and largely written during the lengthy gestation of my appointment to the Seventh Circuit-a period in which the issues discussed in the article assumed a greater than merely academic significance to me. I hasten to add, however, that the views expressed are wholly personal and in no way official.

1 The seminal paper, breaking with the older, predominantly normative tradition, is Stigler, The Theory of Economic Regulation, 2 BBLl J. Econ. \& MGMT. Scr. 3 (1971). For efforts at systematization of Stigler's insights, see Peltzman, Toward a More General Theory of Regulation, 19 J.L. \& Econ. 211 (1976), and G. Becker, A Theory of Political Behavior (Sept. 1981) (Working Paper No. 006-1, Center for the Study of the Economy and the State, University of Chicago) (extensive and up-to-date bibliography); for review essays, see Jordan, Producer Protection, Prior Market Structure and the Effects of Government Regulation, 15 J.L. \& Econ. 151 (1972), and Posner, Theories of Economic Regulation, 5 BrLl J. Econ. \& MGMT. ScI. 335 (1974). 
systematically. There are only brief discussions in the literature on the economic analysis of law, ${ }^{2}$ and none, as far as I know, in the traditional legal literature on statutory and constitutional interpretation. $^{3}$ This article is a start toward filling the gap. The attempt should be of interest not only to students of the economic analysis of law, as well as to theorists and practitioners of statutory construction, but also to economists of the political process. That the economist takes statutes to be complete when enacted is striking to a lawyer, who realizes that the meaning of a statute is not fixed until the courts have interpreted the statute. Judicial interpretation of statutes is thus an intrinsic part of a complete economic theory of legislation, though whether an important part remains to be seen.

It is easy to see how a new view of legislation might require changes, perhaps radical ones, in how courts interpret legislation. It is more difficult to see how the new view might explain what the courts have been doing all along-but my greater interest is in this, the positive question. I believe that the apparent discordance between an economic view of legislation, which emphasizes the efforts of interest groups to redistribute wealth in their favor, and a traditional legal view, which requires the court to divine and effectuate the public interest goal of legislation, is not real; that courts have generally been realistic about legislation; and that the legal tradition in interpreting statutes becomes more, rather than less, intelligible when an economic view of legislation is adopted.

\section{The Economic ApProach to Legislation}

There is now an extensive economic literature on the determi-

2 See R. Posner, Economic ANalysis or Law 408-15, 495-96 (2d ed. 1977); Landes \& Posner, The Independent Judiciary in an Interest-Group Perspective, 18 J.L. \& EcoN. 875 (1975).

3 The lawyers' neglect of the economic theory of legislation is a bit surprising, because though many lawyers find economic concepts alien and repulsive, the most distinctive element in this particular theory-the emphasis placed on the procurement of protective legislation by interest groups-has been a part of the political science literature at least since the discussion of "factions" in The Frderalist No. 10 (J. Madison). See also A. BentLey, The Process of Government (1908); D. Truman, The Governmental Process (1951). In fairness, however, I should point out that Professor Gerald Gunther's proposal for more stringent constitutional review of state economic legislation, see infra notes 64-66 and accompanying text, reflects an awareness of the role of interest groups in procuring legislation. See also infra note 63 . The lawyers' literature on how to read a statute is well represented by $\mathrm{H}$. Hart \& A. Sacks, The Legal Process 1144-1417 (tent. ed. 1958), and F. Frankfurter, Some Reflections on the Reading of Statutes, in Of LAW AND MEN 44 (P. Elman ed. 1956). 
nants of legislation. At least three major theories can be discerned in the literature, though they can, I shall argue, be treated as elements of a single theory.

\section{A. Public Interest Theory}

The "public interest" theory, which is the oldest of the three, is well represented in the writings of such economists as Baumol' and Pigou. ${ }^{5}$ It conceives both the ideal and the actual function of legislation to be to increase economic welfare by correcting market failures such as crime and pollution. Some laws designed to transfer wealth from rich to poor also can be fitted into the theory. Free-rider problems might thwart private efforts to bring about the level of transfers from rich to poor that the rich would prefer; to that extent public wealth redistribution is a public good no different in kind from protection against crime or pollution.

There is little, if any, tension between the economist's public interest theory and the traditional lawyer's view of legislation. ${ }^{\circ}$ The lawyer's view is also that legislation is designed to protect the public interest, implicitly defined in utilitarian terms. If this were the only economic theory of legislation, this article would not be worth writing.

\section{B. Interest Group Theory}

The "interest group" theory asserts that legislation is a good demanded and supplied much as other goods, so that legislative protection flows to those groups that derive the greatest value from it, regardless of overall social welfare, whether "welfare" is defined as wealth, utility, or some other version of equity or justice. ${ }^{7}$ An

- E.g., W. Baumol, Welfare Economics and the Theory of the State (2d ed. 1965).

3 A. Pigou, The Economics of Welfare (4th ed. 1932).

- The traditional view is soon to celebrate its four-hundredth anniversary. See Heydon's Case, 76 Eng. Rep. 637, 638 (Ex. 1584), where the court said that the essential steps in interpreting a statute are to ascertain "[w] wat was the mischief and defect for which the common law did not provide," "[w] hat remedy the Parliament hath resolved and appointed to cure the disease of the Commonwealth," and "[t]he true reason of the remedy; and then the office of all the Judges is always to make such construction as shall suppress the mischief, and advance the remedy." But not every statute that a court is called upon to interpret is intended to correct a mischief; the intent may have been simply to redistribute wealth from a less to a more powerful segment of the community. For a modern statement of the theory of legislation implicit in Heydon's Case, see H. HART \& A. SAcks, supra note 3, at $1410-17$.

T See, e.g., J. Buchanan \& G. Tullock, The Calculus of Consent (1962); A. Downs, an Economic Theory of Democracy (1957); W. Riker, The Theory of Political Coali- 
important determinant of the net benefit of legislative protection to a group, and the primary focus of this literature, is the cost of organizing effective political action. That cost increases as group membership becomes larger and the group less cohesive. The size of the group also bears on the benefits of legislative protection. As the group becomes larger, the benefits to each member are likely to become smaller, and hence the individual's incentive to contribute to the group's endeavor will be weakened. Should the group try to overcome this problem by seeking so large a redistribution that all members would benefit substantially, the redistribution will be much more costly to those outside the group who will be taxed to defray its cost, and this will increase resistance to the group's objective. From an analysis of such factors, the literature concludes that effective interest groups are usually small and directed toward a single issue. The benefits of a redistribution in their favor are concentrated, the costs of organizing the group are small, and the costs of the redistribution are so widely diffused that nobody has much incentive to oppose it.

The properties that make legislative redistributions feasible have nothing to do with the public interest, whether defined in efficiency or equity terms. If anything, they tend to make legislation systematically perverse from a public interest standpoint by fostering the redistribution of wealth from large groups, including the public as a whole, to small ones. From a normative standpoint, therefore, the interest group theory is pessimistic concerning the purpose and effects of legislation, while the public interest theory is optimistic. It is not surprising that the public interest theory flourished in the period when most people favored an expansion of government action, and the interest group theory in the period of disillusionment with big government that began in the 1970's.

The interest group theory, incidentally, has had some distinguished judicial adherents-suggesting that judges may be more realistic about legislation than legal scholars. Holmes said in an early essay:

The struggle for life, undoubtedly, is constantly putting the interests of men at variance with those of the lower animals. And the struggle does not stop in the ascending scale with the monkeys, but is equally the law of human existence. Outside of legislation this is undeniable. It is mitigated by sympathy,

tions 3-31 (1962); G. Stigler, The Citizen and the State (1975). 
prudence, and all the social and moral qualities. But in the last resort a man rightly prefers his own interest to that of his neighbors. And this is as true in legislation as in any other form of corporate action. All that can be expected from modern improvements is that legislation should easily and quickly, yet not too quickly, modify itself in accordance with the will of the de facto supreme power in the community, and that the spread of an educated sympathy should reduce the sacrifice of minorities to a minimum. But whatever body may possess the supreme power for the moment is certain to have interests inconsistent with others which have competed unsuccessfully. The more powerful interests must be more or less reflected in legislation; which, like every other device of man or beast, must tend in the long run to aid the survival of the fittest. ... [ [I]t is no sufficient condemnation of legislation that it favors one class at the expense of another; for much or all legislation does that. . . . The fact is that legislation ... . is necessarily made a means by which a body, having the power, put burdens which are disagreeable to them on the shoulders of somebody else. ${ }^{8}$

Holmes's belief in social Darwinism, evident from the quoted passage, makes him an ancestor of the modern economic theory of legislation as the outcome of a struggle between interest groups. The affinity between economic theory and the theory of biological evolution has often been remarked; ${ }^{8}$ social Darwinism, applied to the legislative process, connects them.

Justice Black's opinion for the Court in Eastern Railroad Presidents Conference $v$. Noerr Motor Freight, Inc. ${ }^{10}$ is another noteworthy example of judicial realism about statutes. The Court in that case held that the Sherman Act ${ }^{11}$ does not prevent collective action to obtain legislation that would hurt competitors. ${ }^{12}$

O.W. Holmes, Herbert Spencer: Legislation and Empiricism, in Justice OLrver Wendell Holmes: His Book Notices and Uncollected LetTrers and PAPERS 104, 107-09 (H. Shriver ed. 1936). Although the essay was written before Holmes became a judge, it describes accurately the attitude that he brought as a judge to the task of determining the constitutionality of legislation.

- For a systematic treatment, see Becker, Altruism, Egoism, and Genetic Fitness: Economics and Sociobiology, 14 J. EcoN. Lrr. 817 (1976).

10365 U.S. 127 (1961).

1115 U.S.C. $\S \S 1-7$ (1976).

12365 U.S. at 136. The defendants in that case had engaged a public relations firm to conduct a publicity campaign designed to foster the adoption and retention of laws harmful to the trucking business. 
Black, whose realism about legislation was rooted not in theory, but in his experience as a United States Senator, stated for the Court:

The right of the people to inform their representatives in government of their desires with respect to the passage or enforcement of laws cannot properly be made to depend upon their intent in doing so. It is neither unusual nor illegal for people to seek action on laws in the hope that they may bring about an advantage to themselves and a disadvantage to their competitors. $^{13}$

By the Court's holding, he said, "we have restored what appears to be the true nature of the case-a 'no-holds-barred fight' between two industries both of which are seeking control of a profitable source of income."14 In another case, ${ }^{15}$ Black rejected the concept of "rationality review"-a rejection clearly implied, as we shall see below, by the interest group approach. ${ }^{16}$

\section{Legislative Process Theory}

The public interest and interest group theories are theories about the content of legislation, the former predicting that it will be efficient (always bearing in mind that efficiency may require some public redistribution of wealth), the latter that it will be amorally redistributive. Some economists, however, have focused on the legislative process itself rather than on the content of the legislation that results. ${ }^{17}$ They have sought to explain, for example, why different sized majorities are required for different types of legislation, why legislatures are frequently bicameral, why there is increasing delegation of legislative authority to administrative

1s $I d$. at 139.

14 Id. at 144 (footnote omitted).

16 Ferguson v. Skrupa, 372 U.S. 726, 731-32 (1963).

16 See infra notes 63-66 and accompanying text. Examples of judicial realism in relation to statutes could be multiplied, but I will give just one more, from Learned Hand. In discussing statutes that made an employer liable to any employee injured as a result of the employer's failure to take the precautions specified in the statutes, Hand stated: "Such statutes are partial; they upset the freedom of contract, and for ulterior purposes put the two contesting sides at unequal advantage; they should be construed, not as theorems of Euclid, but with some imagination of the purposes which lie behind them." Lehigh Valley Coal Co. v. Yensavage, 218 F. 547, 553 (2d Cir. 1914).

17 The seminal works are J. Buchanan \& G. Tullock, supra note 7; A. Downs, supra note 7. 
agencies, and what effects such delegation is likely to have. ${ }^{18}$

\section{A Four-Fold Typology}

There is no incompatibility between either the public interest or interest group theory, on the one hand, and the various theories of legislative process, on the other. Less obviously, there is no necessary incompatibility between the public interest and interest group theories. The public interest theory is mainly concerned with identifying market failures that could, in principle, be rectified by legislation, and its proponents would hardly be willing to shoulder the burden of establishing what proportion of legislation actually enacted is of this character. The interest group theory does not deny the possibility that a large group-perhaps the whole society-occasionally might procure legislation on its own behalf. If the benefits to the individual members of a large group are great enough and the costs to nonmembers small enough (there may be few or even no nonmembers), the legislation will be enacted. There will be free-rider problems, but they need not be insurmountable under the postulated conditions. Laws against murder illustrate this point.

I conclude that the public interest and interest group theories are, at least in some mixture, complementary rather than antagonistic. It should be possible, therefore, to classify statutes between those that advance the public interest and those that advance instead the interest of some (narrow) interest group. A number of statutes clearly belong in one group or another-the basic criminal laws, the original antitrust law, ${ }^{19}$ and the provision of a court system, in the public interest category; the tobacco subsidy, the Interstate Commerce Act, ${ }^{20}$ and the regulation of taxicabs, ${ }^{21}$ in the interest group category.

But these are just polar cases. There are many intermediate

18 On voting majorities, see A. Downs, supra note 7, at 51-74. On bicameralism, see J. Buchanan \& G. TulLock, supra note 7, at 233-48. On delegation, see Ehrlich \& Posner, An Economic Analysis of Legal Rulemaking, 3 J. LEGAL STUD. 257, 279-80 (1974).

10 Sherman Antitrust Act, ch. 647, 26 Stat. 209 (1890) (current version at 15 U.S.C. $\S \S$ 1-7 (1976)).

${ }^{20}$ Interstate Commerce Act of 1887, ch. 104, 24 Stat. 379 (current version in scattered sections of 49 U.S.C. (1976)); see Hilton, The Consistency of the Interstate Commerce Act, 9 J.L. \& ECON. 87 (1966).

${ }^{21}$ See, e.g., ILL. REv. StaT. ch. 24, § 11-42-6 (1979) (authorizing municipalities to license taxicabs); Kitch, Isaacson \& Kasper, The Regulation of Taxicabs in Chicago, 14 J.L. \& EcoN. 285 (1971); cf. R. PosNer, supra note 2, at 267-68 (economic argument that public utility regulations are "interest group" statutes). 
cases, and to fit these into the eclectic theory we need a richer categorization than the public interest/interest group dichotomy. I suggest a four-fold typology, with the economically defined public interest theory and the narrow interest group theory as categories at opposite extremes, and two new intermediate categories: a public interest category defined in terms other than economic, and a "public sentiment" category. ${ }^{22}$

1. Public Interest, Economically Defined. This category is limited to legislation that corrects market failures such as crime and pollution, though as mentioned earlier certain redistributions could be included because they correct failures in the market for charitable giving. ${ }^{23}$ Important examples of laws that serve the public interest economically defined are the provisions of the Constitution that establish the separation of powers and freedom of political speech and thereby protect society against a particularly costly form of monopoly-a monopoly of political power.

2. Public Interest in Other Senses. Whatever one's own conception of the public interest may be, it seems inappropriate to dismiss $a$ priori any other conception that is widely shared. For example, if the progressive income tax can be justified in terms of benefits received, it is in category (1) above; but even if it cannot be justified in those terms, it would still be public interest legislation if justifiable in terms of some widely held concept of the just distribution of wealth. This example also illustrates the equivocal nature of my classification. Many economists regard the progressive income tax either as a means of maximizing utility ${ }^{24}$ - which, depending on one's precise view of the meaning of "economic efficiency,"25 could be part of either category (1) or category (2)-or alternatively as a means of soaking the rich ${ }^{26}$-which would put it

${ }^{22}$ This typology of legislation (broadly defined to include the Constitution) ignores the question of effectiveness, an issue that still dominates the economic analysis of legislation. A fascinating literature, beginning with Stigler \& Friedland, What Can Regulators Regulate? The Case of Electricity, 5 J.L. \& EcoN. 1 (1962), has questioned the effectiveness of a variety of statutes, especially those relating to securities, health, and safety. See, e.g., Peltzman, An Evaluation of Consumer Protection Legislation: The 1962 Drug Amendments, $81 \mathrm{~J}$. Por. Econ. 1049 (1973); Sands, How Effective is Safety Legislation?, 11 J.L. \& Econ. 165 (1968). The finding of these studies that statutes frequently miscarry is strictly empirical and does not explain why ineffectual legislation is enacted. The issue is therefore tangential to this article, which focuses on the determinants of legislation, but it does have some relevance to my analysis. See infra notes 38-39 and accompanying text.

23 See supra p. 265.

24 See, e.g., A. Lerner, The Economics of Control 228-40 (1944).

${ }^{25}$ See R. Posner, The Economics of Justice 48-87 (1981).

${ }^{26}$ See, e.g., M. Friedman, Capitalism and Freedom 161-76 (1962); F. Hayek, The Con- 
into category (4) below (interest group legislation).

3. Public Sentiment. Much legislation cannot be justified or explained on economic grounds, but perhaps only because not enough is known about the relevant costs and benefits. Legislation forbidding the sale of pornography is an example. Such legislation seems at first glance to be an interference with freedom of contract that reduces efficiency, just as a usury law does. But despite the loose use of the term "special interests" in recent political discussion to describe people who feel strongly about an issue, the supporters of laws against pornography do not have the characteristics that make for an effective interest group. And the possible external effects of pornography (on the crime rate, relations within the family, even perhaps population) may, though they have never been quantified, justify the laws and explain the intense hostility that many people feel toward pornography.

Laws based on public sentiment rather than on either an objective weighing of demonstrable pros and cons or on cartel-like pressures for redistributing wealth resemble public interest legislation in that their support seems both broadly based and not motivated by narrow self-interest. But they cannot readily be defended on economic grounds given our existing and deficient knowledge of their effects. They have largely been ignored by economists but their importance in the legislative output requires that they not be ignored in this article.

4. Narrow Interest Group Legislation. Most recent economic analyses of legislation have focused on statutes that appear to promote the narrow self-interest of a particular industry or a group of firms within an industry. Yet what has occurred is less a change than a sharpening of focus, for the change in professional opinion about the economic nature of legislation has resulted largely from a reevaluation of statutes, such as the Interstate Commerce Act ${ }^{27}$ and the Civil Aeronautics Act of 1938, ${ }^{28}$ that were once regarded as legitimate responses to deficiencies or excesses of competition. The interest group theorists have had their greatest success, as one would expect, in explaining legislation applicable to a particular industry, such as the laws regulating the various transportation

\footnotetext{
STITUTION OF LIBERTY 306-23 (1960).

${ }_{27}$ Interstate Commerce Act of 1887, ch. 104, 24 Stat. 379 (current version in scattered sections of 49 U.S.C. (1976)).

${ }^{28}$ Ch. 601,52 Stat. 973 (current version at 49 U.S.C. $\$ \S 1301-1552$ (1976 \& Supp. III 1979)).
} 
and utility industries, occupational licensure laws, and industryspecific tax and subsidy schemes. They have been less successful in explaining economy-wide legislation such as the antitrust laws and health and safety regulations. Some of these laws may, of course, be public interest laws; others may not be. In any event, the boundary between narrow interest group legislation and public interest legislation is indistinct.

\section{Implications of the ECONOMic ANALySis of Legislation for STATUTORY INTERPRETATION}

\section{A. Motive vs. Intent}

I begin with a principle that may seem to belong to constitutional rather than to statutory interpretation: in reviewing a statute, courts are to look to the intent but not to the motive of the enacting legislature. This principle is usually invoked in constitutional cases, where the issue is whether a statute should be invalidated because of the motive behind its enactment. ${ }^{29}$ But it also defines the scope of judicial inquiry into the meaning of a statute in cases where the statute is assumed to be valid and only its application is in dispute. Courts look to the language of the statute, to the legislative history,,$^{30}$ and to other evidence of legislative intent, but they do not speculate on the motives of the legislators in enacting the statute. ${ }^{31}$ They do not, in short, conduct the kind of economic or political science inquiry that might reveal the pattern of interest group pressures behind the statute.

This limitation is of extraordinary interest given the theme of this article. At first glance it may seem diametrically opposed to a realistic view of the political process and may seem to place the judiciary in opposition to the legislative will, even when there is no issue of constitutionality. In fact it is merely inevitable. Courts do not have the research tools that they would need to discover the motives behind legislation. Nor can they just presume the presence of an interest group somewhere behind the scenes. Many statutes

20 The usual answer is "no." See, e.g., Palmer v. Thompson, 403 U.S. 217, 224-25 (1971). The extensive scholarly literature on this issue is well represented by Brest, Palmer v. Thompson: An Approach to the Problem of Unconstitutional Legislative Motive, 1971 Sup. CT. REv. 95; Ely, Legislative and Administrative Motivation in Constitutional Law, 79 YaLe L.J. 1205 (1970); and Legislative Motivation, 15 SAN Drego L. Rev. 925 (1978).

so For possible limitations, see infra notes $35-36$ and accompanying text.

s1 See, e.g., United States v. O’Brien, 391 U.S. 367, 383-85 (1968); McCray v. United States, 195 U.S. 27, 56 (1904); Fletcher v. Peck, 10 U.S. (6 Cranch) 87, 130 (1810). 
really are enacted in the public interest; in those statutes, the actual and the ostensible purposes coincide. Moreover, even where it is obvious that a particular statute was procured by some particular interest group-the National Labor Relations Act ${ }^{32}$ by the labor movement, for example-it will not be clear, at least without an inquiry that is beyond the judicial competence to undertake, how completely the group prevailed upon Congress to do its will. The statute as ultimately enacted may represent a compromise with other groups; if so, the "real" legislative purpose may be unclear.

Therefore, if the legislature wants to indicate the lines of political pressure along which the law should be interpreted, it has to say so explicitly, either in the statute or in the legislative history materials to which courts have ready access. No matter how faithfully judges wish to carry out the will of Congress, they are limited to public materials in divining that will.

This limitation on judicial capacity imposes a further limitation on the operation of interest group politics that is wholly distinct from the limitations that the Constitution may or may not place on that operation. To the extent that legislators use Aesopian language to deceive potential opponents of the interest groups behind legislation, they may fool the courts as well and thereby limit the political power of those interest groups.

This limitation can be reconciled with a normative theory of democratic politics along the following lines. The theory assumes an informed electorate. Although interest groups can take advantage of the limited incentives that voters have to inform themselves concerning public issues, the interposition of a judiciary that, in interpreting legislation, is limited to public materials offsets to some extent the distortions that voter ignorance introduces into the operation of a democratic political system. This is not an argument for free-wheeling statutory interpretation. The point is simply that, however conscientiously the judge tries to follow the legislature's will, he will be limited to the statutory text and to other public materials; he will not ask which interest group got how much of what it wanted from the legislature.

32 Ch. 372, 49 Stat. 449 (1935) (current version at 29 U.S.C. \$§ 151-169 (1976 \& Supp. III 1979)). 


\section{B. Reasoning from One Statute to Another}

In piecing out the meaning of a statute, courts do not use the intent behind one statute to illuminate the intent behind another; that is, they do not treat statutes in the same way that a common law court treats prior cases-as precedents whose reasoning may illuminate the issues in a case. ${ }^{.38}$ This seeming myopia has been criticized ${ }^{34}$ but makes good sense once a realistic view of the legislative process is taken. If some statutes-and the courts will have trouble knowing which ones-reflect the pressures of narrow interest groups rather than any coherent view of the public interest, it is perilous for courts to use one statute to illuminate the meaning of another. There is no assurance that the particular constellation of political pressures that produced the first statute was also at play when the second was adopted. And because the first may have been purely the product of pressure and not of a sincere search for the public good, the first cannot serve as a dependable reason for interpreting the second in a particular way.

\section{Legislative History}

The approach taken in this article casts light on two recurrent issues in the use of legislative history to interpret statutes. The first is whether it is proper to use legislative history at all, and if so, which parts of that history to use. ${ }^{\text {s5 }}$ Because legislators vote on the statutory language rather than on the legislative history, they cannot be presumed to have assented to all that has been said, either in the committee reports or on the floor, about a bill that becomes law.

This matters, however, only if one holds the unrealistic view that each enacted bill reflects the convictions of a majority of legislators voting for it. If instead it is assumed that some unknown fraction of all bills are passed at the behest of politically powerful interest groups, it is not so clear that each member of the legislative majority behind a particular bill has studied the details of the

33 This rule is subject to a narrow exception for statutes in pari materia. See, e.g., Erlenbaugh v. United States, 409 U.S. 239, 243-45 (1972); United States v. Stewart, 311 U.S. 60, 64-65 (1940).

34 See Landis, Statutes and the Sources of Law, in Harvard Legal Essays 213 (R. Pound ed. 1934).

35 For controversy over these questions, compare Radin, Statutory Interpretation, 43 HaRv. L. Rev. 863 (1930) with Dickerson, Statutory Interpretation: A Peek Into the Mind and Will of a Legislature, 50 IND. L.J. 206 (1975). 
bill he voted for. It may be more realistic to assume that he assented to the deal struck by the sponsors of the bill. The terms of the deal presumably are stated accurately in the committee reports and in the floor comments of the sponsors (otherwise the sponsors will have difficulty striking deals in the future), though not necessarily by opponents of the bill, who may take the floor or write minority opinions in committees to create a specious legislative history that they hope will influence judicial interpretation of the statute.

This picture is especially persuasive if we assume a considerable amount of "log rolling"- that is, vote trading-in the legislative process. Log rolling implies that legislators often vote without regard to their personal convictions. This process makes it unrealistic to demand that each legislator assent only to those aspects of statutory meaning that are fixed in the language of the bill, divorced from the intentions of its sponsors as reflected in their statements in the committee reports and on the floor.

$\mathrm{My}$ analysis is also germane to the question what weight to give post-enactment expressions of legislative intent. The answer it suggests, which is also the traditional answer, ${ }^{36}$ is that such expressions should be given little or no weight. The deal is struck when the statute is enacted. If courts paid attention to subsequent expressions of legislative intent not embodied in any statute, they would be unraveling the deal that had been made; they would be breaking rather than enforcing the legislative contract. Nor, if one takes seriously the interest group theory of politics, can subsequent expressions of legislative understanding be treated simply as impartial interpretations of the law; they are as likely to be a gambit in the practice of interest group politics.

\section{Implied Rights of Action}

A statute often will provide for criminal or other public remedies for its violation but not say whether private individuals can bring damage or injunctive actions to enforce it. The present analysis may shed some light on whether a private right of action can be "implied" in a statute that is silent on private remedies, a ques-

s6 See, e.g., Oscar Mayer \& Co. v. Evans, 441 U.S. 750, 758 (1979); United States v. Wise, 370 U.S. 405, 411 (1962). For a striking exception to the conventional approach, consider the recent practice of the California courts in receiving courtroom testimony on legislative intent from legislators, discussed in Comment, Statutory Interpretation in California: Individual Testimony as an Extrinsic Aid, 15 U.S.F.L. Rev. 241 (1981). 
tion that has become controversial in recent years. ${ }^{37}$

The question has an antecedent in the interplay between the standard of care in negligence cases and criminal safety statutes. Suppose a legislature passes a statute forbidding people to drive automobiles faster than fifty-five miles per hour, and someone violates the statute, injuring another as a result. If the victim of the accident sues the injurer, may violation of the statute be used as evidence, perhaps conclusive, of the injurer's negligence? The answer could depend on one's theory of legislation. The public interest theory implies that a legislative-pronouncement on safety should be given great weight: the legislature was honestly trying to determine an optimal safety standard, and it has tools not available to courts for making such determinations. ${ }^{38}$ The interest group approach implies, to the contrary, that there is no presumption that a legislative safety standard represents a sincere effort at optimal safety, so courts should give it no more weight in private cases than the legislature prescribed. Under this view, if there is no evidence that the legislature wanted the standard used in private cases, courts should not use it. The recurrent finding in the economic literature that legislated safety standards are perverse or ineffectual, quite apart from whether they serve some group's special interest, reinforces this conclusion. ${ }^{39}$

The choice between theories of legislation has implications for four specific issues regarding the use of legislated standards in tort cases, and for one issue regarding an implied private right of action to enforce a statute that does not explicitly provide for such a remedy.

1. Legislative Intent. As already suggested, if the interest group view is taken the only question for a court asked to use a

${ }^{37}$ For analysis, see Stewart \& Sunstein, Public Programs and Private Rights, 95 Harv. L. REv. 1193 (1982). The Supreme Court has in a short period swung from enthusiasm for implied rights of action to hostility. For example, compare Bivens v. Six Unknown Named Agents of Fed. Bureau of Narcotics, 403 U.S. 388 (1971) (private cause of action for money damages available under fourth amendment for warrantless search) and J.I. Case Co. v. Borak, 377 U.S. 426 (1964) (private cause of action available under section 27 of the Securities Exchange Act of 1934) with Kissinger v. Reporters Comm. for Freedom of the Press, 445 U.S. 136 (1980) (neither Freedom of Information Act, Federal Records Act of 1950, nor Records Disposal Act confer private right of action) and Touche Ross \& Co. v. Redington, 442 U.S. 560 (1979) (no private cause of action available under section 17(a) of the Securities Exchange Act of 1934).

${ }^{38}$ This seems to be the thrust of Ezra Ripley Thayer's influential analysis of the impact of statutes on the standard of care in negligence cases. See Thayer, Public Wrong and Private Action, 27 Harv. L. REv. 317, 321-23 (1914).

so See supra note 22 . 
statutory standard in a private case is whether the legislature intended to require such use. The issue of legislative intent does not arise under the public interest view, where the only question is whether the legislative standard is pertinent to the issues in the case. The test most often used by tort courts-whether the plaintiff claiming the benefit of the statute was one of the people whom the legislature was trying to protect ${ }^{40}$ - seems to come to the same thing: an inquiry into the relevance of the standard to the case at hand.

2. Technical Invalidity. Suppose a statute containing a safety or health standard is enacted but later is invalidated because of some technical defect in the enactment process. Should the statute nonetheless be given weight by a court in a private action involving the subject matter of the statute? Again the answer depends on one's theory of the legislative process. The public interest theory implies that the defective statute should be given effect unless the defect raises a doubt whether the statute really reflects the deliberate choice of the legislature; ${ }^{41}$ a purely technical defect does not nullify the information content of the statute. Under the interest group view of legislation, however, there is no presumption that a statute has any such content. The courts bow to the legislative determination only as a matter of power; if the legislation is defectively enacted, it is not an authentic exercise of legislative power and therefore should not influence, let alone bind, the courts. ${ }^{42}$

3. Federal Standards in State Courts. If a state court is asked in a private tort action to derive the applicable standard of care from a federal safety statute, the choice between theories of

40 W. Prosser, Handbook of the Law of Torts $\S 36$, at 192-95 (4th ed. 1971). See, e.g., Fitzwater v. Sunset Empire, Inc., 263 Or. 276, 502 P.2d 214 (1972) (snow-clearing ordinance creates duty in favor of the municipality only); Akers v. Chicago, St. P., M. \& O. Ry., 58 Minn. 540, 60 N.W. 669 (1894) (railroad yard safety statute not designed to protect trespassers).

4 See Clinkscales v. Carver, 22 Cal. 2d 72, 136 P.2d 777 (1943) (technical invalidity does not affect applicability of legislative standard); W. Prosser, supra note $40, \S 36$, at 191-92.

12 The same result should follow in the courts' use of health or safety standards enacted by the legislature after the commission of a tortious act. Under the public interest theory, courts should give the standard effect because it embodies the legislature's judgment of the proper standard of reasonable care. See Fall v. ESSO Standard Oil Co., 297 F.2d 411 (5th Cir. 1961) (subsequently enacted statute prohibiting sale or possession of switchblade knives used to demonstrate that a switchblade knife is a dangerous weapon). Under the interest group approach, however, the standard reflects legislative power only and should be given no effect, for that power had not been exercised at the time of the tortious conduct. 
legislation may again be decisive. Courts that adopt the public interest view presumably should use any pertinent federal standards, because the standards can be assumed to provide information on whether the defendant was negligent. But under the interest group approach, courts have no reason to pay any attention to federal statutes, unless the statutes bind state courts by preempting any inconsistent state determinations on issues within their scope.

4. Tortious Acts Outside the Legislative Purpose. In Gorris $v$. $S c o t t,{ }^{43}$ the defendant violated a statute that required animals to be penned on shipboard. The purpose of the statute was to prevent contagion; the plaintiff's animals were washed overboard, although they would not have been had the defendant penned them as the statute required. The court held that the defendant's violation of the statute did not make him liable. This is the usual result in such cases, ${ }^{44}$ but viewed from a public interest standpoint is difficult to understand. If the defendant violated the statute, he acted wrongfully, and liability would have the salutary effect of increasing the incentives to observe the statutory command. But if the statute was just a favor to some interest group, adding sanctions for its violation via the tort law may upset the deal struck in the legislature by giving the interest group more than it could obtain in the political arena.

5. Implying a Private Right of Action. In deciding whether a statute creates a private cause of action for those injured by its violation, courts frequently ask whether the statute creates an adequate set of public remedies for its violation, so that implied private remedies are not needed to enforce it effectively. If courts find the statutory remedial scheme so incomplete or defective that private remedies are necessary to make it enforceable, they are more likely to imply a private remedy. ${ }^{45}$ This result is defensible only under the public interest theory of legislation. The absence of ef-

is 9 L.R.-Ex. 125 (1874).

14 See W. Prosser, supra note 40, \& 36, at 195.

is See, e.g., J.I. Case Co. v. Borak, 377 U.S. 426 (1964) (private right of action implied under section 14(a) of the Securities Exchange Act of 1934); Breitwieser v. KMS Indus., Inc., 467 F.2d 1391 (5th Cir. 1972) (rejecting private right of action under the Fair Labor Standards Act), cert. denied, 410 U.S. 969 (1973). The Supreme Court has become hostile to implying private rights of action and may no longer be willing to do so even if the remedial scheme is defective. In fact, the Court currently is reluctant to recognize a private right of action unless Congress indicates that it intended to create one. See, e.g., Touche Ross \& Co. v. Redington, 442 U.S. 560, 568-78 (1979) (no private right of action found under section 17(a) of the Securities Exchange Act of 1934). Under the analysis in this article, this is the correct approach if the interest group theory of legislation is adopted. 
fective remedies implies to the interest group theorist that the group that procured the legislation lacked the political muscle to get an effective statute, and it is not the business of the courts to give an interest group a benefit that was denied by the legislature. Under this view, to imply a private right of action is to intervene in the legislative struggle on the side of one interest group, overriding opposing groups that had managed to thwart the enactment of an effective statute. The issue is identical to that in Gorris.

The public interest and interest group theories of legislation have very different implications for the proper use of statutes in private cases. But as I argued in part I, we are not limited to a binary choice, and this gives rise to a puzzle: if the output of a legislature is a mixture of public interest and interest group statutes, together with others (based on "sentiment") that are difficult to classify into either group, and if, moreover, courts lack the research tools they need to classify statutes correctly, what is the judge to do when asked to rely on a statute in a private case as a source either of the standard of care or of the underlying right of action? As a matter of logic, it seems he cannot act at all without determining whether a statute is motivated by public interest or interest group considerations-a determination beyond his competence.

Because there is no easy way out of this dilemma, I am led to predict that courts will act with apparent inconsistency. Casual empiricism supports this prediction. Not only has the Supreme Court veered sharply in recent years in its attitude toward implying private rights of action, ${ }^{46}$ but courts asked to use criminal statutes in tort cases have responded inconsistently. An example will show this. ${ }^{47}$ By relying on criminal statutes to determine a standard of care without regard to the legislature's intentions regarding such a use, courts implicitly embrace the public interest theory of legislation. However, by refusing to use statutes for this purpose in cases not envisaged by the legislature, as in the Gorris $v$. Scott line

16 See supra note 45.

17 For other examples, see W. Prosser, supra note 40, $\S 36$, at 194-95. Compare Ross v. Hartman, 139 F.2d 14 (D.C. Cir. 1943) (statute requiring motor vehicles to be locked intended to protect against accidents involving car thieves), cert. denied, 321 U.S. 790 (1944) and Heiting v. Chicago, R.I. \& P. Ry., 252 Ill. 466, 96 N.E. 842 (1911) (railway fencing statute intended to protect children) with Kiste v. Red Cab, Inc., 122 Ind. App. 587, 106 N.E.2d 395 (1952) (ignition key statute not intended to protect against car accidents involving the intervening negligence of thieves) and Di Caprio v. New York Cent. R.R., 231 N.Y. 94, 131 N.E. 746 (1921) (railway fencing statute not intended to protect children). 
of cases, ${ }^{48}$ courts shrink from a full embrace of the public interest approach. Judicial uncertainty regarding the use of statutes in private cases is well illustrated by a federal district court decision holding both that (1) the sternness of the remedies prescribed for violations of the Occupational Safety and Health Act ("OSHA") 49 precludes implying a private right of action ${ }^{50}$ and that (2) a state court would not rely on OSHA as a source of the standard of care in a tort suit. ${ }^{\text {s1 }}$ If my analysis is correct, the first holding implies adoption of the public interest view of legislation and the second implies its rejection. ${ }^{.2}$

\section{E. The Construction of Criminal Statutes}

Although the canons of statutory construction have received well-merited criticism on grounds of fatuity and inconsistency, ${ }^{\mathrm{DS}}$ the "rule of lenity," utes more narrowly than those that provide only civil remedies, usually escapes criticism as long as unnatural constructions are avoided. Economic analysis suggests the following explanation. Every statute overdeters to a certain extent, because its bounds are uncertain and fear of inadvertent liability causes some people to steer well clear of those bounds. The harsher the sanctions for violation, the greater the overdeterrence and the resulting costs in socially beneficial conduct forgone. Overdeterrence can be reduced by careful specification of the statutory limits. If a statute is intended to be specific, courts should not construe it broadly.

This assumes that the legislature is sensitive to the costs of overdeterrence-in other words, that it wants considerations of efficiency to guide judicial interpretation of its product. Not all criminal statutes can be interpreted in this light, but I assume most can

48 See supra notes $43-44$ and accompanying text.

4929 U.S.C. \$§ 651-678 (1976).

so Otto v. Specialties, Inc., 386 F. Supp. 1240, 1242-43 (N.D. Miss. 1974).

${ }^{81}$ Id. at 1244-45 (applying Mississippi law).

32 For a very different view of why courts apply statutory norms in common law adjudication, stressing moral factors, see Michelman, Norms and Normativity in the Economic Theory of Law, 62 Minn. L. REv. 1015, 1016-27 (1978).

${ }^{83}$ For good treatments, see Friendly, Mr. Justice Frankfurter and the Reading of Statutes, in Felix Frankfurter: The Judge 30 (W. Mendelson ed. 1964), reprinted in $\mathrm{H}$. Friendly, Benchmarks 196 (1967); K. Llewellyn, The Common Law Tradition: Deciding ApPEALS 521 (1960).

s4 See, e.g., Dunn v. United States, 442 U.S. 100, 112 (1979); United States v. Wiltberger, 18 U.S. (5 Wheat.) 76, 95-96 (1820); Hall, Strict or Liberal Construction of Penal Statutes, 48 HaRv. L. REv. 748 (1935). 
be. If this assumption is true, then the courts' inability to distinguish on a statute-by-statute basis between public interest and interest group motivations for legislation implies that they should treat all criminal statutes as public interest statutes and assume that the legislature would want the statute interpreted narrowly.

A statute can underdeter as well as it can overdeter, and if overdeterrence is the characteristic vice of broad construction, underdeterrence is the characteristic vice of narrow construction. But the costs are not symmetrical. The harsher the sanction for a violation of law, the higher the cost-justified level of care in drafting. Careful drafting avoids both underdeterrence and overdeterrence. If the legislature can be assumed to draft criminal statutes more carefully than civil statutes, then courts should construe criminal statutes more narrowly than they construe civil statutes-and they do.

Not all criminal sanctions are more severe than civil sanctions. The antitrust laws illustrate this point. The maximum criminal fine that can be imposed on a corporation for violating the Sherman Act is one million dollars, ${ }^{55}$ but trebling of civil damages ${ }^{56}$ makes two-thirds of every private damages judgment for violation of the Sherman Act penal. Thus there is no limit to the amount a corporation might be forced to pay in a civil suit under the Sherman Act. The question of when civil penalties should be equated with criminal sanctions and therefore be governed by stricter procedural safeguards is beyond the scope of the present inquiry. ${ }^{57}$ But I do think that a statute that provides for civil penalties comparable in severity to typical criminal sanctions should be interpreted as narrowly as a criminal statute covering the same subject matter. In antitrust cases, therefore, treble damages should be awarded only where there would be criminal liability. I do not contend that the rule of narrow construction that I am proposing for statutes that impose civil penalties is constitutionally required; thus the suggested reform would require amending the antitrust

ss 15 U.S.C. $\S \S 1-2$ (1976).

ss Id. \$ 15.

37 The Supreme Court's jurisprudence in this area approaches complete deference to congressional labeling. See United States v. Ward, 448 U.S. 242, 248-51 (1980) (deference to congressional decision that penalty under the Federal Water Pollution Control Act was civil); Atlas Roofing Co. v. Occupational Safety and Health Review Comm'n, 430 U.S. 442, 449-50 (1977) (deference to congressional decision that OSHA administrative proceedings are not subject to the seventh amendment). See generally Charney, The Need for Constitutional Protections for Defendants in Civil Penalty Cases, 59 Cornell L. Rev. 478 (1974). 
laws, which now entitle any plaintiff who proves actual damages to a trebling of them.

\section{IMPLICATIONS FOR CONSTITUTIONAL INTERPRETATION}

\section{A. Strict or Loose?}

There is great debate today, as always, over how strictly constitutional provisions should be construed. I do not want to enter the debate; ${ }^{68}$ it is enough for my purposes to observe that virtually everyone who writes on the question thinks that constitutional provisions should not be construed as strictly as statutory provisions. I want to consider whether there are any economic reasons supporting looser construction of constitutional provisions, without worrying how much looser that construction is or should be.

I once thought the most powerful reason for looser construction of constitutional provisions was the cost of amending the Constitution relative to that of amending a statute. But this reasoning is superficial; it merely invites the courts to amend the Constitution through loose construction. There is a better reason for construing the Constitution less strictly than statutes. The Framers made it difficult to amend the Constitution because an easy amendment policy would create instability in the nation's fundamental institutions. ${ }^{59}$ But this does not mean they necessarily rejected liberal construction of constitutional provisions by the courts (or would have done so if the question had been put to them), for construction is unlikely to change the nature of the instrument as radically as amendment. Text and history provide some check on construction (though in some eras precious little), but none at all on amendment. This argument resembles my earlier view but is more persuasive because it derives not from the Constitution's amendment clause but from a contrast between what courts can do to an instrument through construction and what a constitutional convention or a legislature can do through amendment.

There is another reason for construing the Constitution less strictly than statutes, though if this reason is operative the term

${ }^{88}$ I do point the reader to two excellent and brief defenses of the tradition of judicial self-restraint that are easily overlooked: P. DEvin, The Judge as Lawmaker, in THE JuDgE 1 (1979); L. Hand, How Far is a Judge Free in Rendering a Decision, in The SpIRIT of LIBERTY 103 (I. Dilliard 3d ed. 1960).

${ }^{39}$ See Dellinger, The Recurring Question of the "Limited" Constitutional Convention, 88 YALE L.J. 1623, 1625 (1979). 
"loose" may be a misnomer. It is extraordinarily difficult to ascertain the intent of a document drafted two hundred years ago or, as in the case of the fourteenth amendment, even one hundred years ago. The cultural, political, and even linguistic setting is so altered that reconstructing the intent behind the constitutional provisions becomes a task of historical research. Judges do not have the time or the training to do such difficult research; even when it is done by competent legal historians it often yields highly uncertain results. If the intended meaning of a provision is difficult to recover because of the passage of time, any construction of the provision (except one that denies it any contemporary application at all) will seem "loose" to opponents of that construction. It would be more accurate to say that uncertainty over intended meaning increases the variance of defensible interpretations around the (unascertainable) true meaning, for the court is as likely to undershoot as to overshoot the mark.

Although we tend to think of the problem of unrecoverable meaning as one peculiarly of constitutional interpretation, the point is not limited to the Constitution. It applies to any very old statute, such as the Sherman Act, ${ }^{60}$ enacted in 1890 and not significantly amended since. There is as much warrant for departing from the literal meaning of the Sherman Act as for departing from the literal meaning of the fourteenth amendment.

If historical research should yield an unambiguous answer regarding the meaning of a particular constitutional provision, the question would arise whether a court interpreting the provision today should feel bound by the historical understanding. If, but only if, a contrary meaning is well established in precedent, I would answer "no." Legal principles that have been well settled for a century or more should not exist at the sufferance of historians, so that a piece of brilliant historiography could change the public policy of the nation at a stroke. This conclusion, related to the policies that underlie stare decisis and statutes of limitations, does not necessarily flout the intent of the Framers. They were practical men rather than ideologues; they probably would not have wanted the country to pay a big price for correcting mistakes in interpretation many years after such mistakes had been made and after the country had adapted to them.

The disruption of established institutions is a less acute prob-

${ }^{60}$ Ch. 647,26 Stat. 209 (1890) (current version at 15 U.S.C. $\S \S 1-7$ (1976)). 
lem in the case of old statutes. If legislative history of the Sherman Act turned up conclusively proving that the Act was intended to protect competitors rather than consumers, so that ninety years of judicial construction were unsound, Congress could restore the judicial interpretation with the stroke of a pen. It could not do the same thing if the American Historical Society certified that the due process clause of the fourteenth amendment had not been intended to place any substantive limitations on state action.

I am advocating a more limited role for historical research with regard to constitutional provisions that have a long-settled construction than with regard to equally old statutes, but the argument also reinforces in a different way the case for looser construction of constitutional than of statutory provisions. If constitutional provisions are characteristically old and hence difficult to interpret, constitutional adjudication is inescapably more difficult than statutory construction because the courts lack the usual assistance of an intelligible text and a meaningful legislative history. Thus we can expect the incidence of error in constitutional adjudication to be higher than in statutory adjudication. We must therefore decide which kind of error is more costly: the erroneous denial of the legislative will expressed in a statute (or in administrative or executive action thereunder) invalidated on constitutional grounds, or the erroneous denial of a constitutional right. I believe that the erroneous invalidation of a statute is generally more costly, especially if interest group legislation is only a fraction of all legislation. It must generally be better to thwart the desires of a small group seeking to get from the courts what, by definition, it was unable to get from the political branches than to thwart the will of the majority, even if not every statute embodies the will of the majority.

Because I am speaking only of cases where the meaning of the Constitution is unclear, my conclusion does not place the minority at the mercy of the majority and thereby deny the very concept of a constitutional right. If someone has a clear constitutional right, it must be enforced. But if a court cannot honestly determine whether such a right exists, the right should be denied; doubts should be resolved against the claimant. ${ }^{61}$

This conclusion may hold even if most statutes are assumed to be the product of interest group pressures. Such legislation reflects

B1 This was urged in Thayer, The Origin and Scope of the American Doctrine of Constitutional Law, 7 HARv. L. REv. 129, 144 (1893). 
and expresses the dominant power in the community, and it is the counsel of prudence for courts to yield to the dominant power when to do so does not deny a clear constitutional right. Prudence-call it, if you will, timidity in the face of superior power-is an acceptable tie-breaker where, by hypothesis, courts' interpretive tools yield no clear answer to a claim of constitutional right. ${ }^{62}$

In short, all other arguments aside, the utilitarian notions that underlie most versions of welfare economics, coupled with considerations of political prudence frankly imported from outside economics, indicate that, in general, constitutional rights should be narrowly construed but constitutional powers broadly construed. The qualification "in general" is important, though, because if the meaning of a constitutional provision is clear, the problem of construction does not arise.

\section{B. Rationality Review}

I have explained elsewhere why I think the interest group theory of legislation shows the fallacy of invalidating legislation on the ground that it is not rationally related to a proper legislative purpose. ${ }^{63}$ Because no one seems to think it improper for interest groups to influence the legislative process, it cannot be right to invalidate legislation just because it was procured by an interest group. Yet that would be the effect of rationality review if it were taken seriously and applied neutrally, for legislation passed on behalf of an interest group typically will flunk any test of rationality other than pure self-interest. It is a different matter if such legislation infringes people's express constitutional rights. But that is not the issue where legislation is invalidated merely as irrational, for there is no express constitutional right not to be disadvantaged by the characteristic operation of the political process.

Responding to the problem of interest groups that use voter ignorance to subvert the ideal operation of the democratic system, ${ }^{64}$ Professor Gerald Gunther has proposed that legislation not reasonably related to the legislators' stated end be held to violate the equal protection clause of the fourteenth amendment. ${ }^{65}$ The

62 This was Holmes's position. See supra note 8 and accompanying text.

os See R. Posner, supra note 2, at 495-96; Linde, Due Process of Lawmaking, 55 NeB. L. REv. 197 (1976). For a criticism of my analysis, see Michelman, Politics and Values or What's Really Wrong with Rationality Review?, 13 CreIGHTON L. REv. 487, 503-06 (1979).

* See supra p. 273.

ss Gunther, The Supreme Court, 1971 Term-Foreword: In Search of Evolving Doc- 
legislature would be forced to state its actual purpose clearly and so give more information to the electorate. Gunther's proposal is appealing; and though, as he is well aware, it cannot be derived from the text, history, or purpose of the fourteenth amendment, perhaps it is too late in the day to return to the original understanding of the amendment. I have a different point to make: that if my analysis is correct, Gunther's proposal may be redundant. To repeat an earlier point, ${ }^{86}$ if the judiciary is constrained to interpret statutes in accordance with their stated rather than true ends, the ability of interest groups to manipulate an ignorant electorate is automatically limited. No doubt there are cases where the stated objective is so incongruous compared with the actual statutory directive (for example, requiring the licensing of shoe salesmen to limit the spread of athlete's foot) that Gunther's principle would require invalidating the legislation, whereas mere interpretation would allow attainment of the interest group's desires. But a case so transparent to a court may also be transparent to the electorate or its representatives, while if the lack of reasonable connection between means and stated end is not so transparent, the judges are apt to be fooled along with the voters. No doubt there is a middle ground of cases that would be affected by his proposal; the question is how large it would be-it may be small.

\section{Strict Scrutiny}

In recent years the Supreme Court has declared that statutes infringing "fundamental rights" are valid only if they survive "strict scrutiny" of the justifications offered for them. ${ }^{67}$ There can be no objection to this standard-except perhaps that it is too lax ${ }^{88}$ - if the fundamental right in question has firm constitutional roots, as does, for example, the right not to be discriminated against on racial grounds. But when the concept of fundamental rights is expanded to take in a host of interests with no specific constitutional provenance, and when, moreover, most of those interests involve sex or its consequences, ${ }^{69}$ the practical effect of the

trine on a Changing Court: A Model for a Newer Equal Protection, 86 HARv. L. REv. 1, 2021, 23 (1972).

${ }^{68}$ See supra notes 29-32 and accompanying text.

${ }^{67}$ In addition to the cases cited infra note 69, see Shapiro v. Thompson, 394 U.S. 618 (1969) (right to travel); Harper v. Virginia Bd. of Elections, 383 U.S. 663 (1966) (right to vote).

See R. Posner, supra note 25, at 375-76.

69 See, e.g., Zablocki v. Redhail, 434 U.S. 374 (1978) (right of father with prior child 
strict scrutiny standard is to prevent serious consideration of any possible justifications for the challenged statute.

Laws regulating sex fall into the class of statutes that I call "public sentiment" statutes, ${ }^{70}$ for they rest on public feeling rather than on a utilitarian or economic calculus. A strict scrutiny standard asks the state to furnish clear and convincing reasons for the statute; and whatever may be the status of utilitarianism among contemporary philosophers, the reasons that strike judges as clear and convincing are usually utilitarian reasons. ${ }^{21}$ To show that a statute confers a great enough benefit to justify infringing a "fundamental" right requires a showing that the statute promotes a compelling state interest, which in practice means the greatest good of the greatest number. But it is the nature of public sentiment statutes that they are not susceptible of utilitarian justification-and most of the fundamental rights created by the Supreme Court in recent years are rights against constraints imposed by public sentiment statutes on personal behavior. ${ }^{72}$

Indeed, despite all the efforts to ground the fundamental rights approach in antiutilitarian thought, it is difficult to resist the impression that the approach is utilitarianism run wild. Courts perceive the claims of the woman seeking an abortion or of the teen-aged girl seeking the joys of sex unthreatened by pregnancy as claims to happiness not offset by any happiness claim on the other side, with the result that the statutes restricting abortions or denying teenagers access to contraceptives flunk an elementary Benthamite test. So strong is the utilitarian hold over the judicial imagination that even in an area not governed by a strict scrutiny standard-sex discrimination ${ }^{73}$ - the Court prefers a specious utilitarian justification to a frank acknowledgment that a challenged statute rests on public sentiment. For example, in the recent

support obligations to marry without court approval); Carey v. Population Servs. Int'l, 431 U.S. 678 (1977) (distribution of contraceptives to minors under 16); Roe v. Wade, 410 U.S. 113 (1973) (right to abortion); Weber v. Aetna Casualty \& Sur. Co., 406 U.S. 164 (1972) (right of dependent, unacknowledged, illegitimate child to recover under worker's compensation law for death of father); Stanley v. Illinois, 405 U.S. 645 (1972) (right of unwed father to child custody); Eisenstadt v. Baird, 405 U.S. 438 (1972) (use of contraceptives by unmarried people); Stanley v. Georgia, 394 U.S. 557 (1969) (right to private possession of obscene material); Griswold v. Connecticut, 381 U.S. 479 (1965) (use of contraceptives by married people).

70 See supra notes $19-20$ and accompanying text.

${ }^{71}$ For a recent example, see Kaplan, Book Review, 95 Harv. L. REv. 528, 533 (1981).

72 See cases cited supra note 69.

${ }^{73}$ See Craig v. Boren, 429 U.S. 190 (1976) (intermediate scrutiny). 
Michael M. case, ${ }^{74}$ where a young man challenged the constitutionality of his conviction for statutory rape on the ground that the statute did not punish females, the Court upheld the conviction on unconvincing deterrent grounds. ${ }^{25}$ The statutory distinction obviously rested on conventional views regarding the male and female roles in sexual activity rather than on any view that excusing females from liability would have a greater deterrent effect than would making them liable as well as males.

It may seem odd for me to be criticizing the use of a utilitarian calculus to guide constitutional adjudication. But whether or not the fourteenth amendment adopts the felicific calculus, there is a pitfall in using the calculus where only the costs of regulation, and not its benefits, can be measured..$^{78}$ The costs of statutes that limit personal freedom are patent, whether or not they can actually be quantified; the benefits are unmeasurable, yet they may still exceed the costs.

\section{Delegation}

There has been renewed interest lately in the doctrine of nondelegation, which holds that the powers granted to the separate branches of government in the Constitution are not delegable to other branches. ${ }^{77}$ If there is such a principle, it has characteristically been honored in the breach, notably in the creation of independent administrative agencies. These agencies exercise legislative authority without being part of Congress; judicial authority, without complying with the requirements of article III; and executive authority, without being subordinate to the executive. ${ }^{78}$ But I think there is an economic argument, though not necessarily a con-

34 Michael M. v. Superior Court, 450 U.S. 464 (1981).

75 Id. at $469-73$ (statute justified by legitimate state interest in preventing teenage pregnancy).

${ }^{76}$ This is a frequent criticism of cost-benefit analysis in environmental regulation. See, e.g., Anderson, The National Environmental Policy Act, in Federal Environmental Law 301-03 (E. Dolgin \& T. Guilbert eds. 1974); Hammond, Convention and Limitation in Benefit-Cost Analysis, 6 NAT. Resources J. 195, 203-10 (1966).

${ }_{77}$ See, e.g., Industrial Union Dept. v. American Petroleum Inst., 448 U.S. 607, 672-76 (1980) (Rehnquist, J., concurring); T. Lowi, The END of Liberalism 92-126 (2d ed. 1979); Gewirtz, The Courts, Congress, and Executive Policy-Making: Notes on Three Doctrines, Law \& Contemp. Probs., Summer 1976, at 46, 49-65; Scalia, Back to Basics: Making Law Without Making Rules, REG., July/Aug. 1981, at 25.

78. The President can neither remove members of independent agencies before their terms expire nor nullify their actions. See Wiener v. United States, 357 U.S. 349 (1958); Humphrey's Ex'r v. United States, 295 U.S. 602 (1935). 
clusive one, to be made for the constitutionality of the independent agency. Like the argument for construing criminal statutes more narrowly than civil statutes, ${ }^{79}$ it depends on a legislative process analysis rather than on a legislative substance analysis.

It is a peculiarity of legislatures committed to decision by majority vote that they cannot easily be enlarged to meet a greater demand for their output, ${ }^{80}$ as an ordinary business enterprise or government department can be. Adding members to a legislature increases the costs of securing majority agreement and does so at an increasing rate. The formula for the number of separate communication links required to connect all members of a group of $n$ members, $n(n-1) / 2$, will give us a crude idea of the transaction costs involved in legislative production. If the legislature has 100 members, the number of separate links required for a majority is 1275. If the number of legislators is raised to 200 , the number of required links rises to 5050 -almost a four-fold increase, although the number of legislators has only doubled. In short, an expanding legislature encounters severe diseconomies of scale.

This point supplies a practical justification for the delegation of legislative authority to independent agencies. Parallel arguments are available to justify delegation to the agencies of judicial and executive power as well. There must be one Supreme Court, and it would lose its judicial character if its membership were increased very much, as it might have to be if the lower federal courts exercised the judicial power that has instead been vested (subject to only limited review) in the agencies. Expansion of the executive through a proliferation of subordinate officers reduces popular control of the executive branch, because the span of control of the only elected executive official, the President, is limited.

Accepting this justification is not tantamount to endorsing judicial amendment of the Constitution. There is no explicit principle of nondelegation in the Constitution. The Framers could not have foreseen the enormous growth of the nation and presumably did not want to limit the adaptability of the Constitution to remote future conditions, except insofar as they placed explicit limitations on such adaptation. Arguing for constitutional adaptability is different from asserting that courts are free to amend the Con-

79 See supra notes $54-57$ and accompanying text.

so I am speaking of the legislature's legislative output. Legislators have other functions besides the enactment of statutes, and these functions are unaffected by my analysis because they do not depend on majority agreement. 
stitution by interpretation just because the Framers deliberately made amendment by any other route very difficult-a proposition that cannot withstand casual, let alone strict, scrutiny.

But if the suggested interpretation is not usurpative, it may still be wrong. The independent agency, with its combination of legislative, judicial, and executive powers, seems to violate the principle, fundamental in the Constitution's text and history, of the separation of powers. Specifically, the growth of the independent agency may well have placed more power in the hands of the legislature relative to the other branches than the Framers contemplated. Against this consideraton must be set the unreality of expecting the Supreme Court to attempt at this late date to dismantle the administrative state. In these equivocal circumstances, the economic argument outlined above should carry weight.

\section{Fitting the Courts into the Theory}

The economic theory of legislative and constitutional interpretation assumes that courts are simply agents of the enacting body. As Professor William Landes and I have argued elsewhere, ${ }^{81}$ this assumption is not inconsistent with the tradition of judicial independence from political control, for independence is a precondition of the courts acting as agents of the enacting, rather than the current, legislature. Of course, independence from current political pressures does not guarantee that the courts will try to follow the will of the statutory or constitutional draftsmen rather than their own views of proper policy. The discredited canon of statutory construction that statutes in derogation of the common law are to be narrowly construed ${ }^{82}$ is an example of judicial independence asserted to thwart the will of the enacting legislature, and my discussion of constitutional interpretation has revealed many discrepancies between contemporary judicial practice and what the economic theory of constitutional interpretation implies would be the correct practice. To complicate the issue further, courts seeking guidance on the meaning of a statute are limited to the text itself and the published legislative history, and this limitation, as we have seen, reduces the legislature's practical ability to get the courts, however willing they may be, to work its will.

ax See Landes \& Posner, supra note 2.

${ }_{32}$ See, e.g., Pound, Common Law and Legislation, 21 Harv. L. Rev. 383 (1908). Though discredited, the principle is not dead. See, e.g., 3 J. Sutrerland, Statutes and Statutory Construction $\$ 61$ (C. Sands 4th ed. 1974). 
Despite all this, a comparison of the analyses in this article of statutory and constitutional interpretation reveals a greater congruence of the former than of the latter with the economic theory of legislation. A possible reason for this difference is that if courts misinterpret a statute, the legislature can nullify their misinterpretation rather easily through an amending statute. Courts therefore have little to gain by setting their will against the legislature's. Thus a theory that correctly identifies the forces operating on the legislature should also predict the behavior of the courts in interpreting legislation. Courts have much more leeway in interpreting the Constitution, not only because the Constitution is so costly to amend, but also because its antiquity makes it unlikely that the same political forces that procured its enactment are still around to nullify departures from it.

By the same token we would expect, and we find, at least if the antitrust laws are a representative example, less responsible judicial interpretation of old than of recent statutes. This is not only because of the inherently greater difficulty of accurately interpreting the older laws; it also reflects the greater independence from legislative retribution that courts enjoy when they are interpreting very old statutes. 